\title{
The Role of Family Social Support in Decision Making Using Long-Term Contraceptive Methods
}

\author{
Sindi Eka Putri ${ }^{1)}$, Sri Widati ${ }^{2)}$ \\ 1 Health Promotion Unit, Brambang Primary Health Care, Brambang No. 114, Diwek Sub-district, \\ Jombang District, Indonesia \\ 2 Department of Health Promotion and Behaviour Science, Faculty of Public Helth, Universitas \\ Airlangga, Surabaya, Indonesia \\ Email : sindi.eka.putri-2017@fkm.unair.ac.id
}

\begin{abstract}
Background: One of the efforts made by the government to reduce the rate of population growth is through the Family Planning program. Many contraceptive methods are used by Fertile Age Couples (FAC), including the Long-Term Contraception Method or Metode Kontrasepsi Jangka Panjang (MKJP) and the non-Long-Term Contraception Method (nonMKJP). Low interest in fertile-couples for long-term use of contraception cannot be separated from family support to use these contraceptives. There is a need for an understanding of MKJP for FAC. Family support was defined as the attitude, actions, and acceptance of the family of its members. Family members see that those who are supportive are always ready to provide help and assistance. With family support, FAC can easily decide which contraception will be used. Objective: The purpose of this study was to analyze the relationship of family social support to the interest of FAC in using the long-term contraception method in RW 5, Sidotopo Village. Methods: This research was an observational analytic study using a cross-sectional research design. The sample of this research consists of 48 participants, taken randomly using multistage random sampling. The research instrument was in the form of a questionnaire. Then, the data were analyzed using the Chi-square test. Results: The characteristics of family planning acceptors in RW 5 of the Sidotopo sub-district starting from the dominating age are 21-35 years old with high school as the highest level of education. The income level in the area is middle to the upper level from 2 million to 5 million rupiahs per month. Based on the results of statistical tests, there is a correlation between family instrumental social support with the interest of Fertile Age Couples to use MKJP. Conclusion: Based on the results of the bivariate test using Chi-Square, it was found that between the four support variables, only one of them has a relationship that is instrumental support. The results of this study can be used as a rationale for policymaking in order to increase the number of long-term family planning acceptors.
\end{abstract}

Keywords: Contraception, Fertile Age Couple, Long Term Contraception, Social Support

\section{INTRODUCTION}

The implementation strategy for family planning services listed in the Direction Policy for Population and Family Planning Program Strategies. It is a way to increase the acceleration of achievement of the 2015-2019 National Medium Term Development Plan (RPJMN). RPJMN has many programs, one of the programs focuse on being the cultivation of the Population and Family Planning Program. It aimed to increase the use of Long-Term Contraception Method (MKJP) such as Implants, Intra-Uterine Device (IUD),
Female Operating Method (MOW), and Male Contraception Method (MOP). family planning is very beneficial for women themselves, their offspring, and society. Some of those benefits result from increasing the proportion of births that are optimally spaced (Moore et al., 2015).

Based on sources of Performance and Accountability Survey (SKAP), the achievement of the use of MKJP in 2018 has reached $23.1 \%$ of the 2019 RPJMN target of 23.0\% (BKKBN, 2012). The global trend shows that the use of permanent contraception to prevent unwanted pregnancy is high. Although the trend also 
shows a rise in the use of long-acting reversible methods, these are still underutilized despite having contraceptive as well as noncontraceptive benefits. Lack of knowledge among women, dependence on the provider for information, and provider bias for permanent contraception are cited as reasons for this reduced uptake (Joshi, Khadilkar and Patel, 2015).

In 2017, the number of active MKJP participants was $22.8 \%$, while for non-MKJP contraception was $77.2 \%$ (Health Profile of East Java, 2015, 2016, 2017). One of the National Population and Family Agency efforts to reduce the maternal mortality rate is to increase the use of MKJP contraceptives. MKJP is certainly more effective compared to other contraceptive methods. If there are more couples in childbearing age choosing to use MKJP contraceptive method, the programs to address population problem will succeed or at least will be slightly overcome (Surantini, 2018). However, until now not many married couples are interested in using this method. They are more interested in using non-MKJP contraceptive methods. This can be seen from the new Family Planning (KB) participants who tend to prefer injections over other contraceptives. The method of injection contraception has increased, whereas the use of MKJP tends to decrease over time (Hariyani et al., 2014; Aryati, Widyastuti and Sukamdi, 2019).

Low interest in Fertile Age Couples (FAC) for long-term use of contraception cannot be separated from family support. It shows the need for a proper understanding of MKJP for FAC. Family support is the attitude, actions, and acceptance of the family of its members. Family members see that people who are supportive are always ready to provide help and assistance if needed. With family support, FAC can easily decide which contraception that they are going use (Oftikasari and Yanti, 2017).

The population of Surabaya reached 874 millions with male population of 1,420 million, female population of 1,454 million, and the number of FAC is 488,699 couples with a range of active family planning participants in 2017 is $77 \%$. The number of residents of Citizen Association (RW) 5 in Sidotopo sub-district in 2018 was 2,348 residents, consisting of 11 Neighborhood Associations (RT). The number of fertile age couples (EFAs) in RW 5 of Sidotopo is 1,011 couples consisting of age groups of more than 15 years to less than 65 years (Surabaya City Health Office, 2018). The number of active MKJP Family Planning participants in 2018 in RW 5 Sidotopo were 56 participants, while for non-MKJP participants were 216 participants and dominated by injection contraceptive methods.

Various indicators are used as reference for the success of the family planning program. The indicators include the increasing number of family planning participants, a shift in the use of family planning from ineffective to effective contraception, and low birth rates.

From the background above, it is apparent that family planning acceptors in RW 5 Sidotopo sub-district are more tend to choose non-MKJP methods instead of MKJP methods. The choice of contraception for family planning acceptors is inseparable from the social support that comes from family members to family planning acceptors in order to choose the effective contraception.

Social support can be achieved in the form of emotional, instrumental, informative, and appreciation support (Baron, Branscombe and Byrne, 2008). Based on the explanation of background above, it is necessary to conduct further research on "The Role Of Family Social Support In Decision Making Using LongTerm Contraceptive Methods".

\section{METHOD}

This research was an observational analytic that explained the relationship between variables through hypothesis testing without providing treatment because the data was obtained through observation and measurement of research subjects. This study used cross sectional method which was a study used to the dynamics between the phenomena of both factors and effects.

Population of this study was taken from active family planning participants who live in RT 11, RW 5, Sidotopo subdistrict with a total of 273 active family planning participants. The sample of research was taken from active family planning program participants who were 
registered by the cadres and were willing to filled out the questionnaire. The inclusion criterias consisted of active family planning participants, having two or more children, and using non-MKJP or MKJP contraceptive method. The sample was calculated using purposive sampling technique, so that all of the population members had the same opportunity to became respondents. The sample size was 48 which was calculated using the Lemeshow formula. The location of the study was conducted in RW 5, Sidotopo sub-district from February to December 2019.

The research instrument of this study was a questionnaire which consisted of individual characteristics (age, occupational status, monthly income, educational status, and number of children) and the type of social support which the respondents got from their family. As many as ten people were tested before to found out the level of validity and reliability. The variables in this study were divided into two, namely dependent and independent variables. The independent variable in this study was social support, which includes appreciation support, instrumental support, emotional support, and information. The dependent variable was the use of long-term contraception and short-term contraception

The data that had been collected would be processed with editing, coding, scoring, and tabulating. In data processing, social support variables were divided into two categories namely low and high categories. The category is low if the score $\leq 50$ and the high category if $\geq$ 51. This study had ethical clearance certificate with serial number 518/HRECC.FODM/VII/2019.

\section{RESULTS AND DISCUSION}

Sidotopo was a sub-district located in Semampir District, Surabaya. It has a rather dense population compared to other sub-district in the nearby area. Table 1 shows that the distribution of the age group of family planning acceptors are dominated by the first age group (2135 years) $(68.8 \%)$.

The age variable can be used to determine the ideal phase of contraceptive use. The age group below 20 years old is a phase of delayed pregnancy due to underage marriage. While the age group of 20-35 years old is a phase of adjusting the pregnancy gap between 2-4 years, and for age over 35 years are a phase to end pregnancy which is the phase of not wanting to get pregnant again and/or not wanting to have more children.

Table 1. Distribution of Respondents Characteristics in the Area of Sidotopo RW 5

\begin{tabular}{lrr}
\hline \multicolumn{1}{c}{ Variables } & $\mathbf{n}$ & \multicolumn{1}{c}{$\%$} \\
\hline Age (Years Old) & 33 & 68.8 \\
\hline $21-35$ & 12 & 25 \\
$36-55$ & 3 & 6.2 \\
$\geq 55$ & & \\
\hline Education & 1 & 2.1 \\
\hline None & 13 & 27.1 \\
Elementary & 12 & 25.0 \\
Junior High & 20 & 41.7 \\
High School & 2 & 4.1 \\
College & & \\
\hline Income & 2 & 4.2 \\
\hline$\leq 500.000$ & 11 & 22.9 \\
$>500.000-2000.000$ & 35 & 72.9 \\
$>$ 2000.000 - 5000.000 & & \\
\hline Occupational Status & 1 & 13.5 \\
\hline Unemployed & 42 & 55.3 \\
Housewife & 5 & 31.2 \\
Employees & & \\
\hline Number of Children & 10 & 23.2 \\
\hline 1 & 24 & 52.4 \\
2 & 14 & 24.4 \\
\hline 2 & 48 & 100 \\
\hline Total & & \\
\hline
\end{tabular}

A previous research showed a significant correlation between age and the use of contraception methods. As many as 13 respondents under 30 years old used MKJP contraception methods, while 60 respondents over 30 years old tended to use IUD. The study also suggested that age can affect the organ system, organ function, biochemical composition, and hormonal system, so there are differences in the use of contraceptives based on the age period (Triyanto and Indriani, 2018).

The research above is in accordance with research conducted in 2019. It is mentioned that most respondents aged 20-30 years used nonMKJP and respondents who were older than 30 years used MKJP. Women over 30 years should end their pregnancy after giving birth to two or more children (Sumartini and Indriani, 2016). This research is also in line with the research in 2019. It is mentioned that there is correlation between age and the choice of 
contraception method used by respondents. The percentage of respondents between 20-30 years old are classified as safe reproduction and safe reproduction category (Aryati, Widyastuti and Sukamdi, 2019).

There are 20 active $\mathrm{KB}$ participants $(41.7 \%)$ in RW 5 , Sidotopo sub-district who graduated from high school diploma. While the respondents who have no formal education experience is $2.1 \%$.

A study in 2015 mentioned that almost $57.5 \%$ of respondents had low knowledge about contraception (Rokayah and Kurniawati, 2015). It is mentioned that low education level can affect the ability to absorb knowledge. Most of the time, knowledge is obtained from family, family members, and health workers. The level of education is directly proportional to the ability to receive knowledge. The knowledge about contraception methods can help the family planning acceptors to choose what contraception method that really suitable for them.

The real meaning of education is a process of delivered material to the target which aims to change a situation with change in behavior and life goals (Notoadmodjo, 2005). Educational level can influence individual in taking action and finding solutions for existing problems. People can act rationally, so that it will be easier to receive new ideas (Kusuma, 2016).

Table 1 shows that most of the respondents have monthly income between 2,000,000-5,000,000 IDR. The correlation between income and individual's interest in family planning is they can choose a contraception tool that suits their income. A recent study showed that there is no correlation between the level of income and the selection of noneffective contraceptive methods in family planning acceptors in Kenjeran, Surabaya (Kristanto, 2019).

Most of the family planning acceptors were housewives (55.3\%). Statistical test shows that there were no significant influences between respondents' characteristics (age, education, work status, and number of children owned) and the choice of contraceptives method. Women of Childbearing Age who work or has a permanent job will tend to choose effective and efficient contraception, because they do not have to go repeatedly to health services. They will choose MKJP contraceptive method which could limit the number of children certainly, so it does not interfere with career and work. Setting a pregnancy distance for career women is very important. This is related to the jobs they have which aim to support the family economy. However, another research showed that there was no correlation between work and the use of the contraceptive method chosen (Triyanto and Indriani, 2018).

Table 1 shows that 24 out of 48 family planning acceptors in RW 5, Sidotopo sub-district have two children (31.6\%). A previous study showed that most respondents prefer to use non-MKJP contraceptive method since it is more practical when they plan to conceive and restore fertility without visiting health services (Sumartini and Indriani, 2016).

Another research argued that number of children and the level of education has a significant correlation with the choice of contraceptive method. In other research, individual characteristics such as the number of children also affect the KB acceptor in choosing the contraceptive method that will be used. Couples who have a few children tend to choose the type of contraceptive method with low effectiveness, while couples with a large number of live children will tend to choose contraceptive method with high effectiveness (Triyanto and Indriani, 2018).

Social support is support given to individuals who can come from families or community groups. Social support can be in the form of information support, instrumental support, appreciation support, and emotional support. Supporting information to individuals can be in the form of providing information about MKJP. It is given to increasing their insight about MKJP. Instrumental support, for example, accompanies family planning acceptors to visit the primary health care and provides transportation facilities or financial support for them. Appreciation support can be given through gives full support to family planning acceptors to make decision about what contraceptive method to be used. Emotional support can be in the form of giving love to individuals 
when they have related to family planning and contraceptive method.

Table 2 illustrates that the information support in the use of MKJP is lower at $52.1 \%$ by 25 people. One of the influential factors is the presence or absence of information. The information including advice, guidance, and feedback. This result is in line with the results of research conducted in 2014 about husband's support for Female Surgery Method states. Husband did not provide information support to his wife to use female surgery contraceptive method, so that the wife does not clearly know the benefits from it (Muniroh, Luthviatin and Istiaji, 2014).

Table 2. Distribution Frequency Based on Social Support

\begin{tabular}{llr}
\hline \multicolumn{1}{c}{ Social Support } & $\mathbf{n}$ & $\%$ \\
\hline Informative support & & \\
\hline Low & 25 & 52.1 \\
High & 23 & 47.9 \\
\hline Total & 48 & 100 \\
\hline Appreciation support & & \\
\hline Low & 23 & 47.9 \\
High & 25 & 52.1 \\
\hline Total & 48 & 100 \\
\hline Instrumental support & & \\
\hline Low & 23 & 47.9 \\
High & 25 & 52.1 \\
\hline Total & 48 & 100 \\
\hline Emotional support & & \\
\hline Low & 24 & 50 \\
High & 24 & 50 \\
\hline Total & 48 & 100 \\
\hline
\end{tabular}

Family can also provide assistance in the form of information. Information can help individuals find the right alternative for solving problems that might be faced by them. The information support can be in the form of experience, convey the knowledge gained, or provide information sources such as reading material about family planning. Health workers need to promote family planning information to FAC and their families.

Appreciation support is an expression of respect, encouragement to move forward, and help individuals to be able to see the positive side. It can cause the increase of self-esteem and approval of other ideas or feelings. Support that can be given by spouses (husbands) to wives is by giving consent to use MKJP. Table 2 shows that the community of RW 5, Sidotopo sub-district gave more support to family in the use of MKJP (52.1\%). It means that the appreciation support given is at high level.

A research conducted about spouses' support for the use of MKJP mentioned that one of the respondents refused to give their wives' consent to conduct Female Surgery. In accordance with Indonesian culture that the highest decision lies with the head of the family, this causes the wife to follow orders from their spouses (Muniroh, Luthviatin and Istiaji, 2014).

Table 2 illustrates that FAC in RW 5, Sidotopo Sub-District are more likely to provide instrumental support regarding the use of MKJP (52.1\%). This value shows that the instrumental support is included in the high category. The instrumental support given by the family to the FAC is in the form of direct assistance needed by the acceptor. In terms of family planning, instrumental support can be provided such as providing the cost for the use of the MKJP and willing to take the wife primary healthcare for consultation with medical staff. Spouses take role as facilitator to their wives in providing their needs to check reproductive health such as visiting health workers (midwives or doctors) and primary healthcare. The instrumental support provided by the husband to his wife would be very helpful for FAC (Muniroh, Luthviatin and Istiaji, 2014). In addition, from Table 1 it can be illustrated that the FACs in RW 5, Sidotopo Sub-District provide emotional support in the use of MKJP. Table 1 shows the same percentage (50\%) between those who provide emotional support and those who do not provide emotional support.

Emotional support that families can provide to FAC can be in the form of good communication between husband and wife in terms of family planning participation. Table 2 shows that emotional support has a balance value between low and high categories. Communication between FAC is interpersonal communication, which can build, maintain, and establish relationships with new people, old friends, or family members. Such communication can be related to the number of children desired by the FAC.

Family support in family planning program can be in the form of encouragement or motivation that can lead to the belief that individuals feel 
loved and cared. Family support means giving and receiving affection as an ideal lifestyle towards a prosperous small family. Bivariate analysis is used to determine social relations with families using Long-Term Contraception in RW 5, Sidotopo sub-district using the Chi-Square test is shown in Table 3.

Table 3. The Relationship of Family Social Support to the Interest of Fertile Age Couple in the Use of MKJP.

\begin{tabular}{|c|c|c|c|c|c|}
\hline \multirow{2}{*}{$\begin{array}{c}\text { Social } \\
\text { Support }\end{array}$} & \multicolumn{2}{|c|}{ MKJP } & \multicolumn{2}{|c|}{ Non MKJP } & \multirow{2}{*}{$\begin{array}{c}\text { P Value } \\
(0.05)\end{array}$} \\
\hline & $\mathrm{n}$ & $\%$ & $\mathrm{n}$ & $\%$ & \\
\hline \multicolumn{6}{|c|}{ Information Support } \\
\hline High & 2 & 25 & 23 & 57.5 & \multirow{2}{*}{0.13} \\
\hline Low & 6 & 75 & 17 & 42.5 & \\
\hline \multicolumn{6}{|c|}{ Instrumental Support } \\
\hline High & 1 & 12.5 & 23 & 57.5 & \multirow{2}{*}{0.04} \\
\hline Low & 7 & 87.5 & 17 & 42.5 & \\
\hline \multicolumn{6}{|c|}{ Appreciation Support } \\
\hline High & 3 & 37.5 & 20 & 50 & \multirow{2}{*}{0.703} \\
\hline Low & 5 & 62.5 & 20 & 50 & \\
\hline \multicolumn{6}{|c|}{ Emotional Support } \\
\hline High & 3 & 37.5 & 21 & 52.5 & \multirow{2}{*}{0.701} \\
\hline Low & 5 & 62.5 & 19 & 47.5 & \\
\hline Total & 8 & 100 & 40 & 100 & \\
\hline
\end{tabular}

Based on the Table 3, out of the four support variables, only one variable which has a significant correlation, namely instrumental support. Based on ChiSquare test, $P$ Value $=0.04$ was obtained for instrumental support. It can be concluded that there is correlation between instrumental support for the family with the interest of FAC to use MKJP. As a result, three variables such as emotional support, appreciation support and information support do not have significant correlation with the interest of FAC to use MKJP.

Support from husband is not a major factor in the quality of life for IUD contraception acceptors. It shows that the majority of IUD acceptors receive high support of $83.55 \%$ of 66 respondents. The meaning of the support itself is information that can come from others such as verbal and non-verbal information, tangible advice or behavior provided by people close to people such as family or husband in the form of presence in things that can provide emotional benefits and can affect the recipient's behavior ((Caruso, Agnello, Romano, Cianci, Presti, Malandrino, et al, 2011 in Pradanie, Armini and Prastika, 2019)).
The results of the previous research showed that the type of husband support that gets the highest score is emotional support, while the lowest support is information support. The research also mentioned that respondents who received low husband support were as many as 12 respondents (92.3\%) (Pradanie, Armini and Prastika, 2019). Husband or family support will help to improve the family planning acceptors' quality of life of. The majority of the MKJP used by FAC is IUD contraceptive method. This method is quite effective and durable, which has protection level up to 10 years. In addition, IUD is also fairly inexpensive with sufficient levels of efficiency and comfort (Triyanto and Indriani, 2018). The failure rate in the first year was fairly low $(0.8 \%)$. Another advantage of the MKJP is that it does not affect the menstrual cycle and must not have to take pills regularly or continue to visit medical services such as doctors or midwives.

In addition, long term contraceptives such as IUD absolutely has no effect on the sexual environment. The use of IUD does not affect on hormones, which if the contraception acceptor is still in the breastfeeding phase it would not interfere with breast milk production even though the IUD is installed immediately after giving birth. IUD method is a good longterm contraception method because it does not affect fertility even after releasing it. It is flexible, so it can be placed in the uterus and removed easily and safely.

Instrumental support is a type of social support provided by individuals which can be in the form of direct assistance. It can be in the form of provide services of goods. Instrumental support can be done by provide financial support for reproductive check, or provide transportation facilities to visit health services. Based on the results of research conducted in 2017, it was stated that as many as $33.3 \%$ of respondents who had vasectomy received instrumental support from the family. Support provided by the family to respondents can be financial or non-financial (Cahyani, 2017).

Spouses' support includes helping to choose the appropriate contraception, use it correctly, seeking help if complication occur, take their wives to health care facilities for periodical check, and help to find an alternative method if the 
contraception is unsatisfactory (Baron, Branscombe and Byrne, 2008).

The study of effects on weight gain and husband's support with the transfer of Depo Medroxyprogesterone Acetate (DMPA) contraception into injectable birth control showed that spouses' instrumental support can affect wives' decision to switch contraceptive method. Such instrumental support can be in the form of deliver and provide transportation for the wife to re-visit the health center for the contraception (Sulistyaningsih, 2016).

Information support is social support given by family members to family planning acceptors. Informative support can be in the form of giving advice, suggestions or feedback to individuals about contraceptive method and family planning services. Information support such as advice from those that had experienced similar situations will help individual understand the situation, so that they can solve the problems.

The results of this research show that there is no correlation between informative support with the interest of FAC in the MKJP. Some respondents did not give permission to their wives to visit health workers who gave counseling about vasectomy contraception, so respondents did not know clearly about the vasectomy contraception. In addition, there are limited information in terms of mass media both print and electronic in advertising or discussing about male birth control (Cahyani, 2017).

Emotional support is social support given by family members to family planning acceptors in the form of provide motivation, empathy, or care for individuals, so that individuals feel loved. This can be in the form of continuously encouraging individuals when they have problems with their contraception. In this study, there was no significant correlation between emotional support from the family and FACs' interest in MKJP.

The previous research about social support for vasectomy participants showed that the reasons for husbands to undergo vasectomi are because of the wives' health and the wives' complaints on contraception. Therefore, wives allow their husbands to have vasectomies (Cahyani, 2017).

Appreciation support is support given by the family to individuals in the form of positive respect to the individual. It can be also in the form of encouragement and agreement with individual ideas or feelings and positive comparison of that person with others. In family planning, the appreciation that families can give to family planning acceptors is by giving consent to the contraceptive to be chosen.

In this study, there was no significant correlation between the appreciation supports with the FACs' interest in MKJP. $A$ research found that respondents who did not get appreciation support from their partners did not go through vasectomy. It also mentioned that the respondents were given freedom because they are husband. However, the respondents did not get permission from their wives because the fear of its side effects (Cahyani, 2017).

Social support is one of the determining factors for FAC in choosing the contraceptive method to be used. The decision cannot be separated from family social support both emotional support, instrumental support, appreciation support and information support. However, until recently, FAC is tend to choose non-MKJP method instead of MKJP. The use of non-MKJP causes the continuity of the use of contraception to decrease. The government's effort in overcome the population explosion is now re-launching the MKJP contraceptive program. It is a contraceptive method with a relatively long effective period. These method include the Women's Operation Method (MOW), Contraception in the Womb or IUD with a validity period up to ten years, Under-Skin Contraception (AKBK) or implants with a validity period of three years (BKKBN, 2016).

Previous research stated that as many as $60 \%$ of respondents did not know about the contraceptive model correctly. In this research, it is known that respondents' knowledge about contraceptive method is influenced by the level of education. Women who have higher education will be more likely to understand on which contraception is more suitable for them (Manurung, 2015).

This is related to the culture of Indonesians who assume that husband is the main decision maker in the family, so the wife tends to follow them. In family planning program services, husbands should be involved so that they can 
encourage their partners to use contraception that is rational, effective, and efficient in accordance with family planning.

Everything has both negative and positive sides, including the use of contraception that has advantages and disadvantages. Faintness that occurs from the use of contraception is a side effect that is often experienced by the respondents. These side effects such as blood spotting between menstrual cycles and the presence of vaginal discharge that is sometimes excessive. In addition, there are still many women of childbearing age and couples of childbearing age who are still having trouble choosing the type of contraception that should be used. It proves that there is still lack of knowledge possessed by couples of childbearing age about the requirements that must be known and the safety of contraceptive methods.

Support from husband and family is a very important factor in helping family planning acceptors to choose the contraceptive method. Husband and family are the closest people who might be invited to a discussion and are people who can be trusted. The use of contraception will be done if the woman has a strong support from her husband. The husband is more dominant to direct his wife in using contraception and end the contraception that will be used. Moreover, family planning acceptors also need support from their family members as the person who they trust, provide encouragement, and give advice or opinion.

In some behavioral theories, husband or family support is a motivating factor that can influence wife's behavior related to positive behavior. Thus, the health workers need to embrace the husband and family to be able to support the selection of contraceptive methods, so that the family planning program can be implemented successfully.

\section{CONCLUSION}

From the four family support variables, only information support which had the lowest percentage. While for other social support such as appreciation, emotional, and instrumental support have fairly high percentage value. Among the four support variables only one that had a correlation with the use of MKJP, namely instrumental support. Instrumental support has significant relationship to the interest of the FAC in the use of MKJP.

The results of this study can later be used as a basis for policy making related to increase the number of MKJP acceptors through the development of supporting instruments. In addition, it can also be used as a baseline for similar research, particularly in relation to the model and type of instrumental support development for FACs in deciding to choose the right and suitable MKJP.

\section{REFERENCE}

Aryati, S., Widyastuti, D. and Sukamdi (2019) 'Faktor-Faktor Yang Mempengaruhi Pemilihan Metode Kontrasepsi ( Kasus Di Kecamatan Seberang Ulu I Kota Palembang )', 33(1), pp. 79-85. doi: 10.22146/mgi.35474.

Baron, R. A., Branscombe, N. R. and Byrne, D. (2008) Social Psychology. Boston: Pearson Education.

BKKBN (2016) Laporan Kinerja Instansi Pemerintah Tahun 2015.

Cahyani, D. (2017) 'Dukungan Sosial dalam Melakukan Vasektomi di Kecamatan Tanggulangin Kabupaten Sidoarjo', jurnal biometrika dan kependudukan, 6, pp. 171-179.

Hariyani, P. et al. (2014) 'Rendahnya Keikutsertaan Pengguna Metode Kontrasepsi Jangka Panjang Pada Pasangan Usia Subur', Jurnal Biometrika dan Kependudukan, 3, pp. 66-72.

Joshi, R., Khadilkar, S. and Patel, M. (2015) 'International Journal of Gynecology and Obstetrics Global trends in use of long-acting reversible and permanent methods of contraception: Seeking a balance', International Journal of Gynecology and Obstetrics. Elsevier B.V., 131, pp. S60-S63.

doi: 10.1016/j.ijgo.2015.04.024.

Kristanto, R. (2019) 'FAKTOR-FAKTOR YANG MEMPENGARUHI AKSEPTOR KB DALAM MEMILIH METODE KONTRASEPSI NON EFEKTIF DI KECAMATAN KENJERAN KOTA SURABAYA', Jurnal Pendidikan Geografi, 4(3), pp. 16-23.

Kusuma, N. (2016) 'Hubungan antara metode dan lama pemakaian dengan keluhan kesehatan subyektif pada 
akseptor', Jurnal Berkala Epidemologi, 4, pp. 164-175. doi: 10.20473/jbe.v4i2.2016.164.

Manurung, S. (2015) 'Model Pengambilan Keputusan Meningkatkan Akseptor Keluarga Berencana Metode Kontrasepsi Jangka Panjang', Jurnal Kesehatan Masyarakat Nasional, (47), pp. 483-488.

Moore, Z. et al. (2015) 'Missed opportunities for family planning: an analysis of pregnancy risk and contraceptive method use among postpartum women in 21 low- and', Contraception. The Authors, 92(1), pp. 31-39. doi: 10.1016/j.contraception.2015.03.007. Muniroh, I. D., Luthviatin, N. and Istiaji, E. (2014) 'Dukungan Sosial Suami Terhadap Istri untuk Menggunakan Alat Kontrasepsi Medis Operasi Wanita ( MOW ) ( Studi Kualitatif pada Pasangan Usia Subur Unmet Need di Kecamatan Puger Kabupaten Jember )', 2(1), pp. 66-71.

Oftikasari, M. and Yanti, D. E. (2017) 'Hubungan Pengetahuan dan Dukungan Keluarga Terhadap Penggunaan Metode Kontrasepsi Jangka Panjang di Wilayah Kerja Puskesmas Punggur Lampung Tengah Tahun 2016', Jurnal Dunia Kesmas, 6(April), pp. 85-92.

Pradanie, R., Armini, N. K. and Prastika, B. (2019) 'Dukungan Suami Bukan
Faktor Utama Kualitas Hidup Akseptor KB IUD', Pediomaternal Nursing Journal, 5(1), pp. 25-30.

Rokayah, Y. and Kurniawati, R. (2015) 'Analisis Faktor-Faktor yang Berpengaruh Terhadap Perilaku Drop Out KB di Desa Caringin Kabupaten Pandeglang Banten', Jurnal Kesehatan, 6, pp. 1-10.

Sulistyaningsih, I. (2016) 'Faktor - Faktor Yang Mempengaruhi Tingginya Fertilitas Di Kecamatan Tambaksari Kota Surabaya'.

Sumartini and Indriani, D. (2016) 'Pengaruh Keinginan Pasangan Usia Subur ( Pus ) dalam Penggunaan Metode Kontrasepsi Jangka Panjang', Jurnal Biometrika dan Kependudukan, 5, pp. 27-34.

Surantini, S. (2018) 'Pengaruh Program Kampung KB Terhadap Keinginan Pasangan Usia Subur ( PUS ) Dalam Penggunaan Metode Kontrasepsi Jangka Panjang ( MKJP ) di Desa Sei Nagalawan Kecamatan Perbaungan Tahun 2018'.

Triyanto, L. and Indriani, D. (2018) 'Faktor yang Mempengaruhi Penggunaan Jenis Metode Kontrasepsi Jangka Panjang (MKJP) pada Wanita Menikah Usia Subur di Provinsi Jawa Timur', The Indonesian Journal Public Health, 13, pp. 244-255. doi: 10.20473/ijph.vl13il.2018.244-255. 